\title{
Echocardiographic evaluation of systolic heart failure
}

\author{
Queenie Lo and Liza Thomas ${ }^{1,2}$ \\ 'Liverpool Hospital, Department of Cardiology, Sydney, New South Wales 2170, Australia, \\ ${ }^{2}$ The University of New South Wales, Sydney, New South Wales 2052, Australia. \\ Correspondence to Liza Thomas via ASUM. Email author@asum.com.au
}

\begin{abstract}
Echocardiography is the most commonly used modality for evaluating left ventricular size and function in the context of systolic heart failure. Traditional techniques, though extensively used, have their limitations and more recently several newer technologies have emerged that are more reproducible, provide prognostic information, guide therapies and have an important role in monitoring progress. This review will evaluate the traditional and more novel techniques used and briefly provide an overview of the role of echocardiography in guiding and monitoring therapies in patients with systolic heart failure.
\end{abstract}

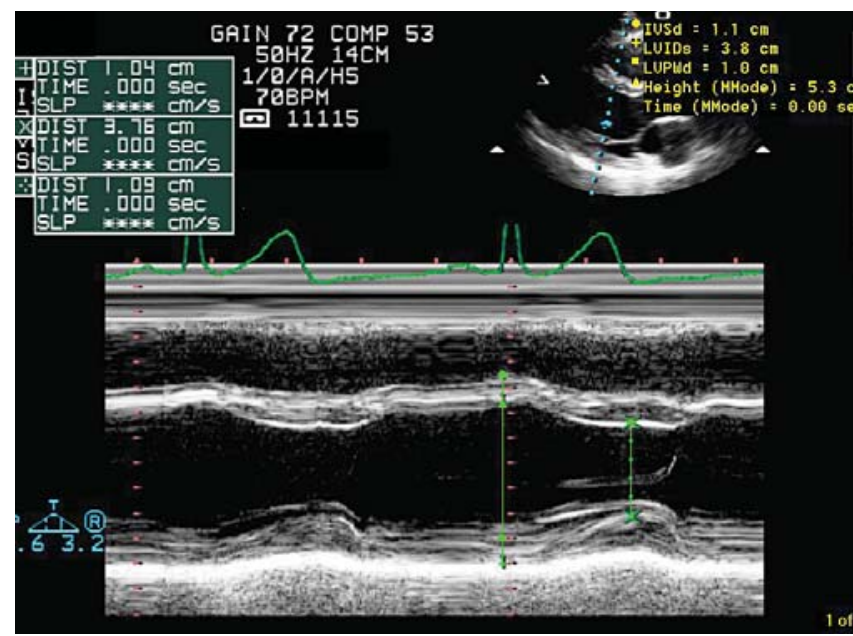

Fig. 1: M-mode echocardiogram of the left ventricle showing septal and posterior wall thickness as well as LV end diastolic and LV end systolic diameters.

\section{Introduction}

Heart failure (HF) is a global health problem, with an estimated 15 million symptomatic patients worldwide'. In 2001, 300,000 Australians had chronic HF with 30,000 new cases diagnosed yearly ${ }^{2}$. HF was the third largest cause of death in $2002^{3}$ while deaths associated with HF accounted for $8.3 \%$ of circulatory deaths ${ }^{4}$. Current guidelines emphasise the importance of early identification of $\mathrm{HF}$ patients for initiation of therapy, thereby containing health care costs ${ }^{5}$. Echocardiography, according to ACC/AHA guidelines is "the single most useful diagnostic test in the evaluation of patients with HF" ${ }^{6}$. This article addresses the utility of echocardiography in systolic HF, with discussion of traditional and newer techniques of assessment.

\section{Traditional measurements}

\section{M mode}

Left ventricular (LV) volumes, ejection fraction (EF) and fractional shortening can be measured by M-mode (Fig. 1) but are only applicable to a symmetrical heart without regional abnormality. Current American Society of Echocardiography (ASE) guidelines recommend two-dimensional (2D) LV volume and EF quantification discouraging

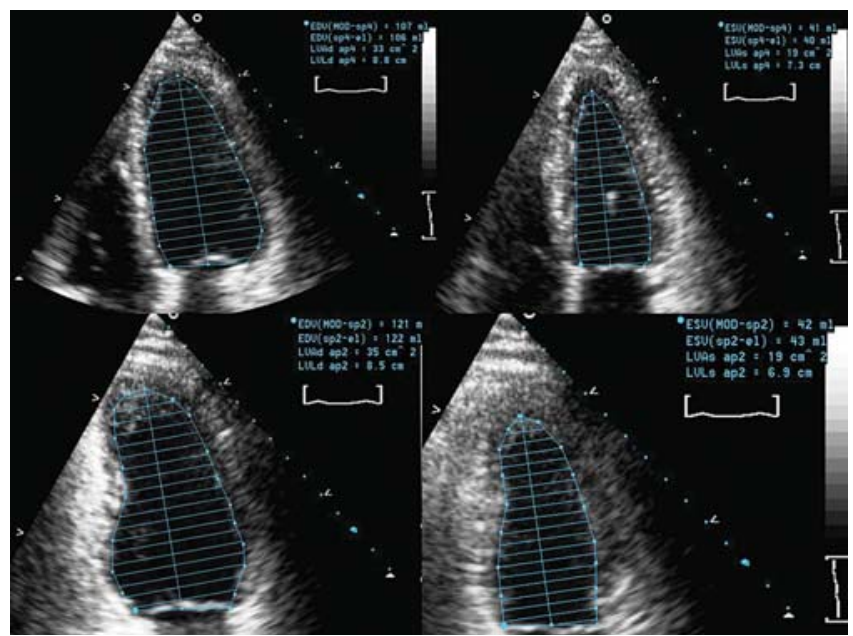

Fig. 2: Apical 4 chamber (top panel) and 2 chamber (bottom panel) modified biplane method of discs measuring LV end diastolic and end systolic volumes.

M-mode measurements that rely on geometric assumptions to convert linear measurements to volumes ${ }^{7}$.

\section{2-dimensional LV volumes}

2D LV end systolic (LVESV) and end diastolic volumes (LVEDV), indexed LVESV (LVESVI) are important predictors of outcome. Current ASE guidelines recommend the modified biplane method of discs for LV volume and EF quantification from apical 4 and 2 chamber views ${ }^{7}$ (Fig. 2), but measurements rely on image quality and inherently underestimate LV volume. However, the V-HeFT ${ }^{8}$, SOLVD ${ }^{9}$ and Val-HEFT ${ }^{10,11}$ trials have shown the close association of these parameters with morbidity and mortality.

White, et al. ${ }^{12}$ showed that LVESVI was an independent predictor of survival and hospitalisation after acute myocardial infarction (AMI), while from the Heart and Soul study, LVESVI was an independent predictor of hospitalisation in patients with stable coronary heart disease (CHD) ${ }^{13}$. From the multicentre BEST study ${ }^{14}$, LVEDVI was a predictor of adverse outcome in advanced HF. Reproducibility of $2 \mathrm{D}$ measurements is a problem with a test-retest variability of $11 \%$, inter-observer and intra-observer variability of $5 \%$ and $3 \%$ respectively ${ }^{15}$. 


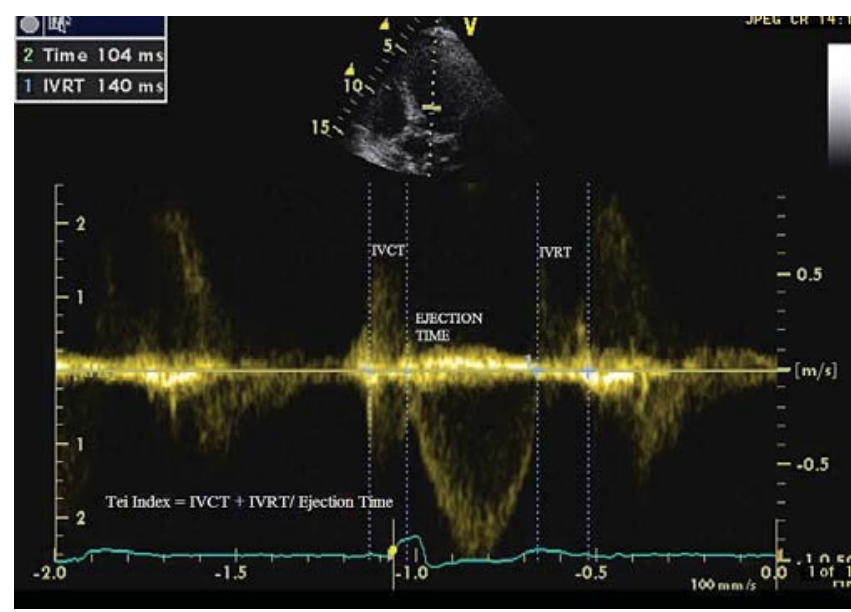

Fig. 3: Tei index calculated as IVCT + IVRT/Ejection time use Doppler.

\section{LV ejection fraction}

LVEF is a parameter of global systolic function that provides a numeric interpretation for the diagnosis and therapeutic guidance in HF management and for device implantation. Despite the fact that LVEF does not correlate with HF symptoms, exercise capacity or myocardial oxygen consumption $^{16}$, it remains a powerful prognostic marker for future cardiac events, especially post $\mathrm{AMI}^{17}$. Curtis, et al. examined the relationship of LVEF to clinical outcomes in 7,788 stable HF patients ${ }^{18}$ and a higher LVEF was associated with a linear decrease in mortality. Additionally, an LVEF $<35 \%$ was the bench mark for intra-cardiac defibrillator (ICD) implantation based on the MADIT I trial ${ }^{19}$.

\section{Wall motion abnormality}

The ASE advocates the use of a 17 segment model, dividing the LV into three levels (basal, mid and apical) with further subdivision into six segments at the basal and mid level and 4 segments at the apical level and a single segment at the apex to produce 17 segments. A wall motion score index (WMSI) can be derived by grading segmental dysfunction severity (normal $=1$, hypokinesis $=2$, akinesis $=3$, dyskinesis $=4)^{20}$. WMSI and LVEF for risk stratification after an $\mathrm{AMI}^{21}$ demonstrated that both were powerful predictors of all-cause mortality, with WMSI being an independent predictor of death and HF hospitalisation.

\section{Ischaemic mitral regurgitation}

Ischaemic mitral regurgitation (MR) is functional regurgitation consequent to infarction with structurally normal leaflets and subvalvar apparatus. Leaflet motion is restricted with apical displacement of the coaptation zone, causing incomplete systolic closure of the mitral valve or "systolic tenting" ${ }_{22}$. Ischaemic MR results from complex alterations of spatial relationships between the LV and mitral apparatus ${ }^{23}$ and a recent study confirmed that MR severity is related to systolic tenting and not LV dysfunction ${ }^{24}$. Ischaemic MR occurring early or late after AMI is associated with increased mortality $^{25,26}$, and severe MR portends poor prognosis ${ }^{27,28}$. Transthoracic echocardiography (TTE) enables analysis of the mechanism and severity of MR, and transoesophageal echocardiogram (TOE) is only occasionally necessary. The quantification of ischaemic MR differs from organic $\mathrm{MR}^{26}$ with thresholds for severe ischaemic MR being $30 \mathrm{~mL}$ for regurgitant volume and $20 \mathrm{~mm}^{2}$ for ERO, compared with 60 $\mathrm{ml}$ and $40 \mathrm{~mm}^{2}$ respectively, in organic $\mathrm{MR}^{26,29}$.

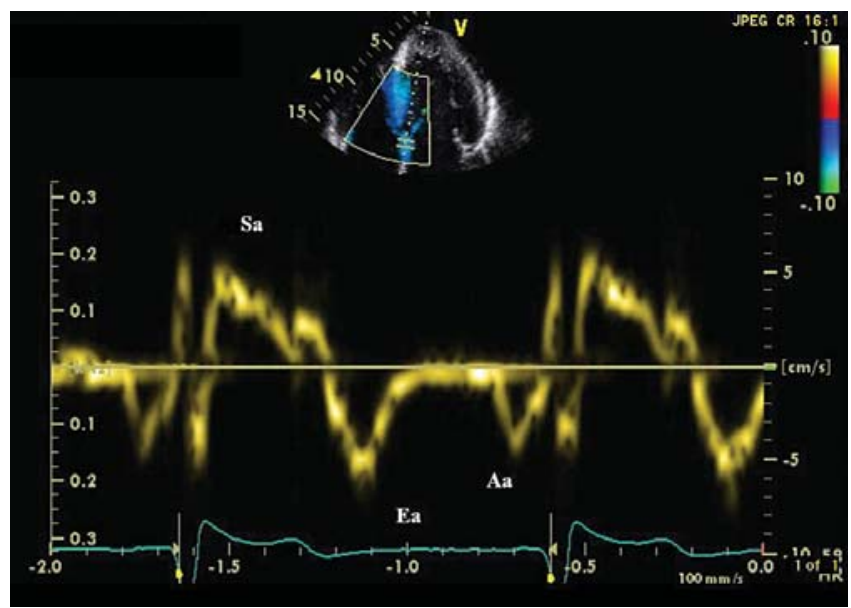

Fig. 4a: Pulse wave tissue Doppler imaging from the septal mitral annulus demonstrating the systolic Sa and diastolic Ea and Aa velocities.

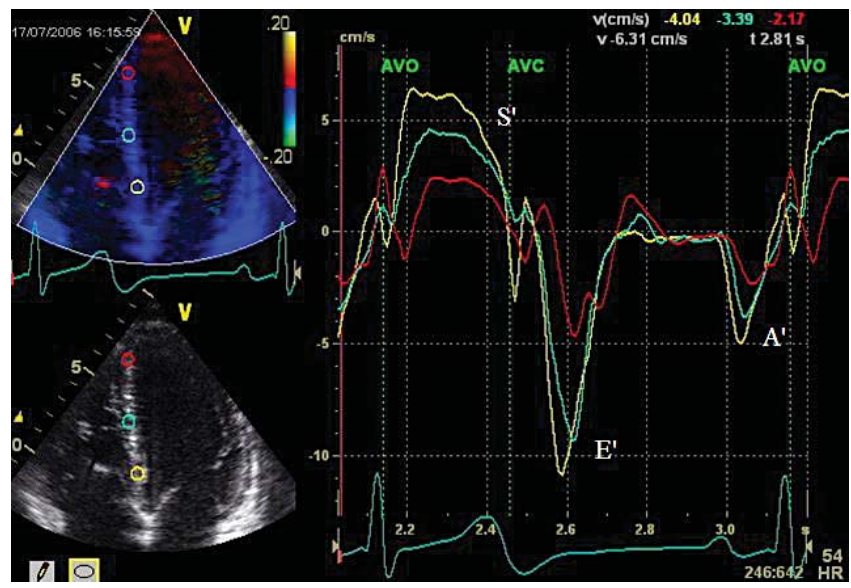

Fig. 4b: Colour tissue Doppler imaging with the offline curves obtained demonstrating the systolic $S^{\prime}$ and diastolic $E^{\prime}$ and $A^{\prime}$ velocities.

\section{Tei Index}

The myocardial performance index, or Tei index, reflects global performance incorporating both systolic and diastolic function. The Tei index is the ratio of the sum of isovolumic contraction and relaxation times to the ejection time, with these parameters obtained from Doppler assessment (Fig. 3). The Tei Index is independent of heart rate, blood pressure, does not rely on geometric assumptions, is highly reproducible ${ }^{30}$ and correlates with invasively measured LV $\mathrm{dP} / \mathrm{dt}^{31}$. The Tei Index has prognostic value in various patient cohorts $^{32}$ and an index $>0.77$ proved superior to LVEF in predicting death ${ }^{33}$. Other studies have shown its value in prediction of HF in an elderly cohort ${ }^{34}$ as well as predicting lack of treatment response in patients with $\mathrm{HF}^{35}$.

\section{Newer parameters and application}

Newer echocardiographic techniques utilising tissue Doppler imaging (TDI) and strain (S) and strain rate (SR) imaging are more robust and reproducible, providing quantitative assessment of global and regional function.

\section{Tissue Doppler imaging}

TDI uses low-velocity, high amplitude myocardial velocity signals ${ }^{36}$ and is obtained by pulsed Doppler (Fig. 4a) or colour Doppler (CTDI) (Fig. 4b) function ${ }^{37}$. CTDI acquires tissue velocity information from the entire sector and thus multiple sites can be interrogated simultaneously and analysed offline. Pulsed Doppler measures peak velocity and 


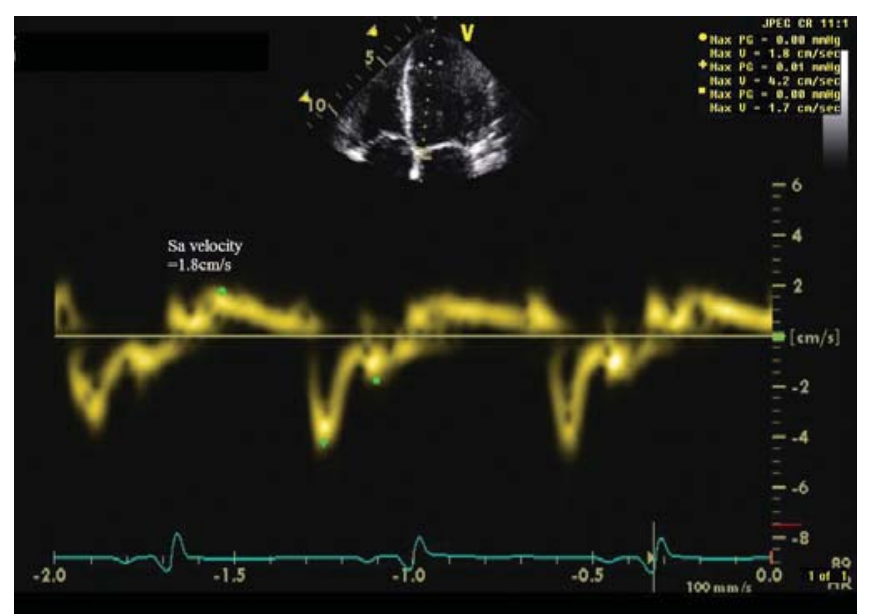

Fig. 5: Pulse tissue Doppler imaging from the septal mitral annulus in a patient with ischaemic cardiomyopathy. Note the significant decrease in Sa velocity correlating with the systolic dysfunction.

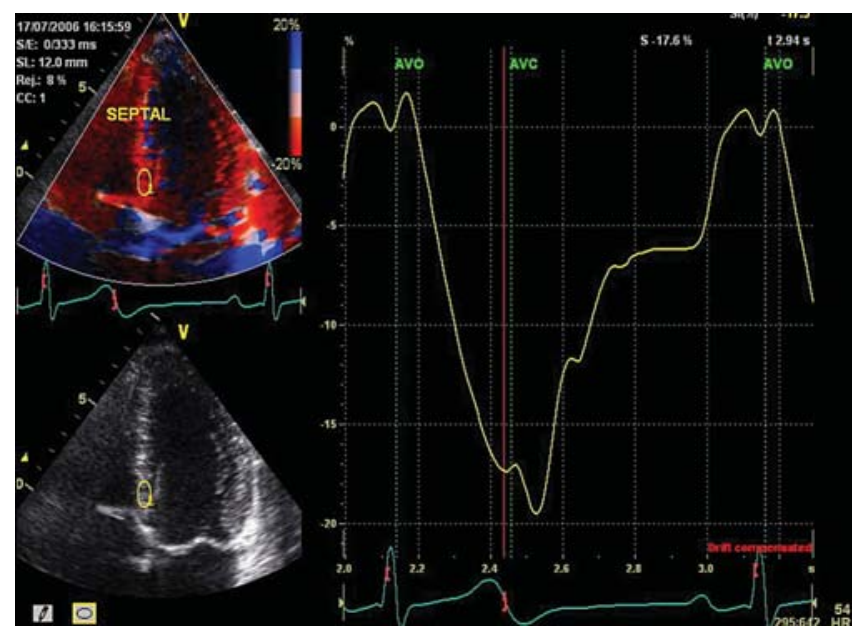

Fig. 6a: Ventricular strain trace obtained with sample volume placed in the basal ventricular septum.

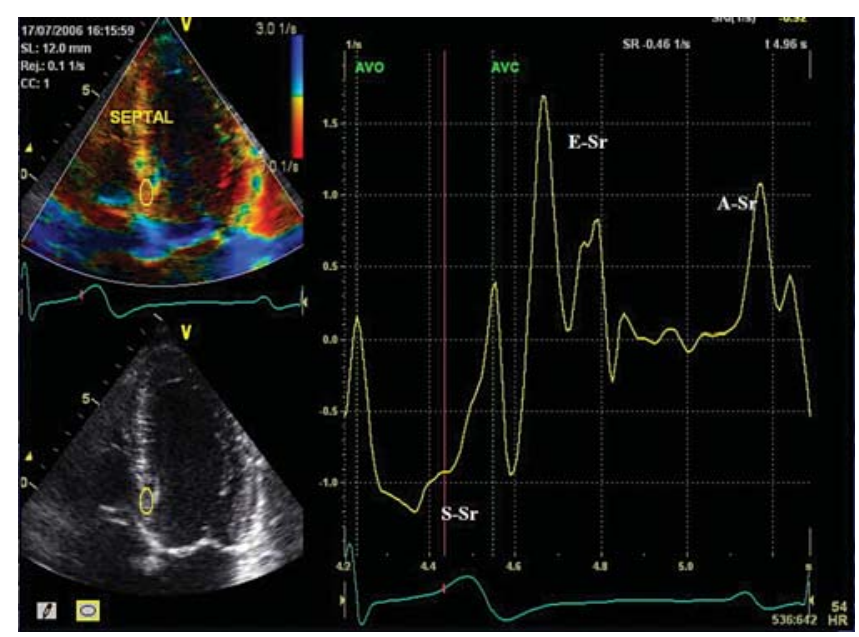

Fig. 6b: Ventricular strain rate trace obtained with sample volume placed in the basal ventricular septum demonstrating systolic $\mathrm{S}-\mathrm{Sr}$ and diastolic $\mathrm{E}-\mathrm{Sr}$ and $\mathrm{A}-\mathrm{Sr}$.

is $\sim 20-30 \%$ higher than the mean velocity measured by $\mathrm{CTDI}^{38}$.

TDI has been validated extensively in a variety of cardiac pathologies including $\mathrm{HF}^{39}, \mathrm{AMI}^{40}$, hypertension ${ }^{41}$, diabetes ${ }^{42}$ and in stress echocardiography ${ }^{43}$ where TDI systolic velocities are used as an adjunct to $\mathrm{WMSI}^{44}$. The peak systolic septal annular $(\mathrm{Sa})$ or basal septal segmental velocity $(\mathrm{Sm})$
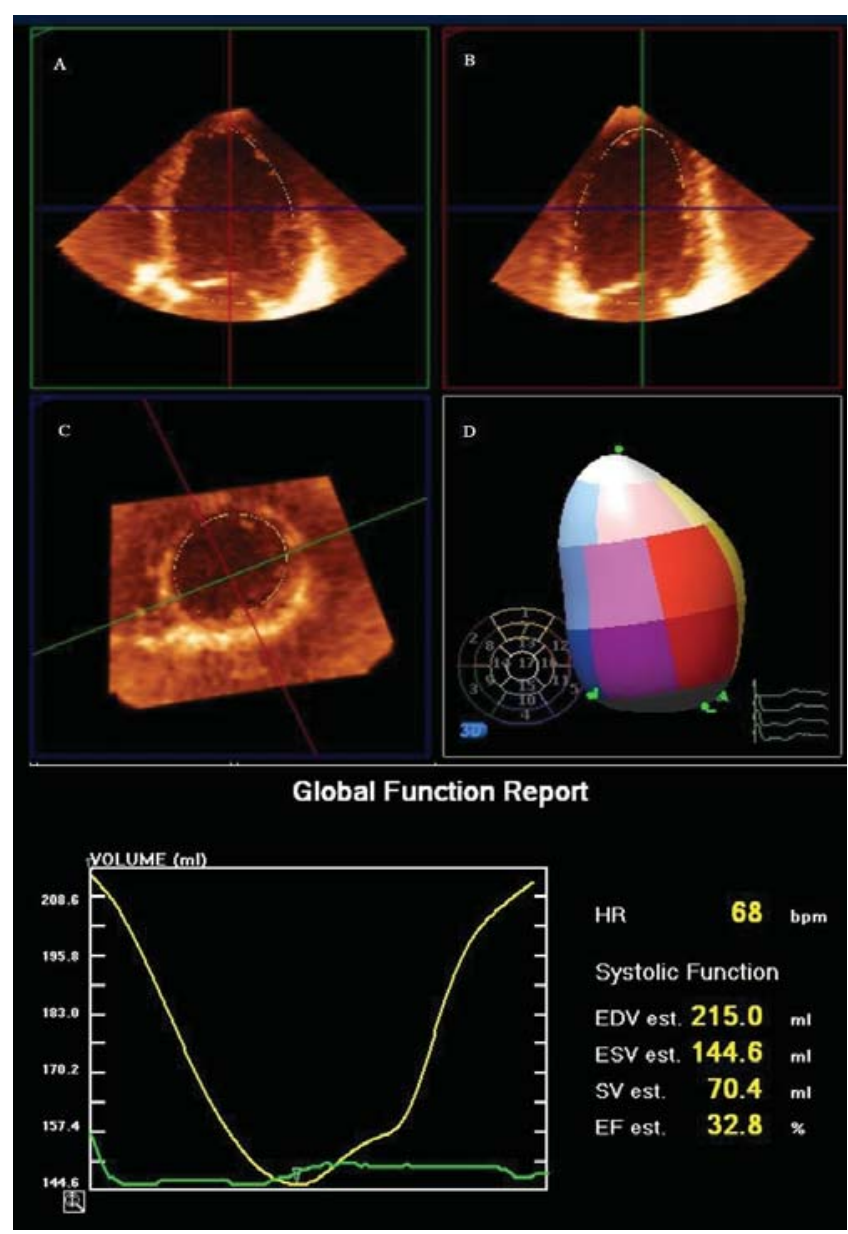

Fig. 7: Real time 3-dimensional echocardiography demonstrating LV contour tracing in the two apical and parasternal short axis views (panels A-C). Panel D demonstrates the 3D LV volume and the bottom panel demonstrates graphically, LV volume change over the cardiac cycle.

is a sensitive marker of impaired LV systolic function, even in those with a normal $\mathrm{LVEF}^{45}$. Sm velocity is a predictor of outcomes and in patients with cardiac disease, mortality was higher when $\mathrm{Sm}$ was $<3 \mathrm{~cm} / \mathrm{s}^{46}$. In HF patients, CTDI $\mathrm{Sm}$ velocity and diastolic arterial pressure were independent predictors of outcome ${ }^{47}$.

\section{Strain and strain rate}

Strain (S) is a measure of tissue deformation, defined as the change in length normalised to the original length, whilst strain rate (SR) measures the rate of deformation ${ }^{48}$ (Figs. $5 \mathrm{a}, 5 \mathrm{~b})$. Strain imaging is derived from $\mathrm{TDI}^{49}$ and more recently from 2D myocardial speckle-tracking ${ }^{50}$. Unlike TDI measurements, S and SR are not subjected to cardiac tethering $^{51,52}$. Normal ranges for S and SR have been described ${ }^{53}$, and while $S$ is influenced by increasing age, pre-load and after-load, SR is less load dependent. S and SR can detect subclinical disease in hypertension ${ }^{54}$ and diabetes ${ }^{55}$ as well as infiltrative myocardial disease ${ }^{56}$, correlates with myocardial fibrosis ${ }^{57}$ and has been used to evaluate therapeutic response $^{58}$. S and SR have been used in stress echocardiography $^{56}$. SR correlates with myocardial perfusion during dobutamine stress ${ }^{59}$ and is superior to TDI in detecting $\mathrm{CAD}^{60}$. S and SR are reduced in ischaemia/infarction with augmentation in viable segments ${ }^{61}$.

\section{Diastolic parameters}

Several diastolic parameters such as deceleration time and 
Table 1: Strengths and weaknesses of various echocardiographic techniques.

\begin{tabular}{|c|c|c|c|}
\hline Parameter & Utility & Strengths & Limitations \\
\hline M-Mode & $\begin{array}{l}\text { - Part of standard TTE } \\
\text { assessment } \\
\text { - Available on all U/S } \\
\text { systems }\end{array}$ & - Easy to perform & $\begin{array}{l}\text { - Relies on geometrical assumptions } \\
\text { - Off axis imaging } \\
\text { - Dependent on image quality }\end{array}$ \\
\hline $\begin{array}{l}\text { 2D volume } \\
\text { (biplane modified } \\
\text { Simpsons method) }\end{array}$ & $\begin{array}{l}\text { - Assess global LV function } \\
\text { - Used to monitor therapy }\end{array}$ & $\begin{array}{l}\text { - Powerful prognostic marker } \\
\text { of outcomes in HF and CAD }\end{array}$ & $\begin{array}{l}\text { - Underestimates volume due to inherent } \\
\text { foreshortening } \\
\text { - Dependent on image quality } \\
\text { - Lacks reproducibility }\end{array}$ \\
\hline $\begin{array}{l}\text { Ejection fraction } \\
\text { (biplane modified } \\
\text { Simpsons method) }\end{array}$ & $\begin{array}{l}\text { - Estimates global systolic } \\
\text { function } \\
\text { - Widely used } \\
\text { - Guides medical, device } \\
\text { therapy }\end{array}$ & $\begin{array}{l}\text { - Powerful prognostic marker } \\
\text { for future cardiac events in } \\
\text { HF and post AMI }\end{array}$ & $\begin{array}{l}\text { - Poor correlation with HF symptoms or ex } \\
\text { capacity } \\
\text { - Load dependent } \\
\text { - Dependent on image quality }\end{array}$ \\
\hline $\begin{array}{l}\text { Wall motion score } \\
\text { index }\end{array}$ & $\begin{array}{l}\text { - Semiquantitative score } \\
\text { of } \\
\text { segmental dysfunction }\end{array}$ & $\begin{array}{l}\text { - Easy to perform } \\
\text { - Predictor of death and } \\
\text { hospitalisation post AMI }\end{array}$ & $\begin{array}{l}\text { - Requires adequate visualisation of all } \\
\text { segments } \\
\text { - Visualisation of lateral segments } \\
\text { problematic }\end{array}$ \\
\hline Tei Index & $\begin{array}{l}\text { - Reflects global } \\
\text { performance } \\
\text { - Incorporates systolic and } \\
\text { diastolic function }\end{array}$ & $\begin{array}{l}\text { - Independent of HR, BP } \\
\text { - Highly reproducible } \\
\text { - Prognostic value in HF }\end{array}$ & $\begin{array}{l}\text { - Less accurate in atrial fibrillation and } \\
\text { pacing } \\
\text { - Partial preload dependence }\end{array}$ \\
\hline TDI & $\begin{array}{l}\text { - Estimates myocardial } \\
\text { velocity signals }\end{array}$ & $\begin{array}{l}\text { - Independent of 2D quality } \\
\text { - Prognostic in cardiac } \\
\text { disease } \\
\text { - Detects subclinical LV } \\
\text { dysfunction }\end{array}$ & $\begin{array}{l}\text { - Subject to cardiac tethering } \\
\text { - Less accurate in AF, pacing } \\
\text { - Requires TDI soft ware }\end{array}$ \\
\hline Strain/ Strain rate & $\begin{array}{l}\text { - Measures tissue } \\
\text { deformation and its time } \\
\text { course }\end{array}$ & $\begin{array}{l}\text { - Independent of tethering } \\
\text { - Detects subclinical disease } \\
\text { - Correlates with fibrosis } \\
\text { - Viability /ischaemia with } \\
\text { stress echo }\end{array}$ & $\begin{array}{l}\text { - Strain age and load dependent } \\
\text { - Technically difficult and time consuming } \\
\text { - Currently mainly research tool }\end{array}$ \\
\hline Dyssynchrony & - Multiple techniques & $\begin{array}{l}\text { - Quantitative monitor for } \\
\text { CRT }\end{array}$ & - Modest correlation to CRT benefit \\
\hline Real time 3D & $\begin{array}{l}\text { - Acquires full volume } \\
\text { data set } \\
\text { - Global and regional } \\
\text { quantification }\end{array}$ & $\begin{array}{l}\text { - Eliminates geometrical } \\
\text { assumptions } \\
\text { - Identifies true LV apex } \\
\text { - Low intra/inter observer } \\
\text { variability }\end{array}$ & $\begin{array}{l}\text { - Not readily available/ accessible } \\
\text { - Time consuming with offline analysis }\end{array}$ \\
\hline
\end{tabular}

$\mathrm{AMI}=$ acute myocardial infarction, $\mathrm{AF}=$ atrial fibrillation, $\mathrm{BP}=$ blood pressure, $\mathrm{CAD}=$ coronary artery disease, $\mathrm{CRT}=\mathrm{cardiac}$ resynchronisation therapy, $\mathrm{HR}=$ heart rate, $\mathrm{HF}=$ heart failure, $\mathrm{LV}=$ left ventricular, $\mathrm{TDI}=$ tissue Doppler imaging, $\mathrm{TTE}=$ transthoracic echocardiogram, $\mathrm{U} / \mathrm{S}=$ ultrasound. restrictive filling ${ }^{62}$ and decreased diastolic TDI velocities ${ }^{63}$ are associated with poor prognosis in systolic HF. An E/Ea $>15$ is a powerful prognosticator for adverse cardiac events ${ }^{64}$ and is an independent predictor of cardiac mortality and HF hospitalisation ${ }^{65}$. However, these diastolic parameters will not be discussed in this current review.

\section{Dyssynchrony}

Uncoordinated ventricular motion or "mechanical dyssynchrony" is often present with LV dysfunction and is associated with a prolonged QRS complex. However, not all patients with a wide QRS complex exhibit dyssynchrony ${ }^{66}$; $30-50 \%$ of patients with a narrow QRS complex may have echocardiographic dyssynchrony that benefits from cardiac resynchronisation therapy $(\mathrm{CRT})^{67,68}$. Echocardiography is the most widely used modality for dyssynchrony and techniques include M-mode, TDI, speckle tracking, and realtime 3D echocardiography (RT3DE).

The simplest method for evaluating dyssynchrony is Mmode analysis of posterior wall to septal delay with $\geq 130$ ms predicting HF improvement with $\mathrm{CRT}^{69}$. Pulsed-wave TDI is performed on line and generally considered more difficult and time-consuming. CTDI is most commonly used and measures time from QRS onset to peak systolic velocity (TPSV). Bax and colleagues defined dyssynchrony as the maximum difference in TPSV between the four basal (anterior, inferior, septal, lateral) segments ${ }^{70}$ and TPSV difference of $65 \mathrm{~ms}$ had a sensitivity and specificity of $80 \%$ for predicting reduction in death and HF hospitalisation. Yu, et al. developed a 12-segment model involving six basal 
and mid segments from the three apical views and deriving the standard deviation (SD) between the 12 measurements, thereby creating a dyssynchrony index ${ }^{71}$. A SD $\geq 32 \mathrm{msec}$ identified dyssnchrony and correlated with a favourable CRT response ${ }^{72,73}$. Similarly, speckle tracking can assess dyssynchrony ${ }^{74}$ as also RT3DE that examines the time to minimum systolic volume (TMSV) $)^{75,76}$.

\section{LV torsion}

LV twist or torsion describes the wringing motion of the LV and represents the net difference in clockwise and counterclockwise rotation of the LV apex and base ${ }^{77}$. Torsion occurs because of the varying orientation of the myocardial fibres; subendocardial fibres have a longitudinal orientation $\left(\sim 80^{\circ}\right)$ relative to the mid-wall where the fibres are circumferentially orientated $\left(0^{\circ}\right)$, and changes to an oblique orientation $\left(-60^{\circ}\right)$ subepicardially ${ }^{78}$.

During isovolumic contraction, the LV apex shows brief clockwise rotation that reverses rapidly and becomes counterclockwise during LV ejection ${ }^{79,80}$, followed by untwisting (clockwise rotation) during early diastole. In contrast, rotation of the base is lower in magnitude and opposite in direction. Torsion is a function of LV contractility and varies linearly with $\mathrm{EF}^{81}$ while "untwisting" correlates with the relaxation time constant $(\tau)^{82}$. Both TDI and speckle tracking can measure torsion and correlate with MRI ${ }^{83,84}$. Twist mechanics can be applied in disease states; in hypertension, diastolic LV untwisting was delayed and reduced in parallel to the severity of LV hypertrophy ${ }^{85}$, while in AMI patients, apical LV twist was severely depressed ${ }^{86}$.

\section{Real time 3D echocardiography}

RT3DE employs matrix array transducers that acquire real time full volume data sets ${ }^{87}$. The recently validated RT3DE volumetric quantification of global and regional LV function $^{88}$ overcomes limitations of 2D echocardiography as it eliminates geometric assumptions, identifies the true LV apex and evaluates wall motion encompassing all planes ${ }^{89}$. Jenkins, et al..$^{90}$ demonstrated the correlation of RT3DE to MRI with lower intra and inter observer variability, whilst comparing it to computed tomography, Sugeng, et al.$^{91}$ have shown its superiority in LVEF and volume measurement. RT3DE can assess LV dyssynchrony and demonstrated a greater improvement from CRT with RT3DE guided LV lead placement ${ }^{92}$. RT3DE is superior in ischaemic MR quantification as it visualises the true vena contracta and proximal flow convergence ${ }^{93}$ especially with eccentric MR.

\section{Role of echocardiography in therapeutic intervention}

Echocardiography has a valuable role in guiding and monitoring HF therapies as discussed below.

\section{Medical therapy}

Current ACCF/AHA HF guidelines ${ }^{6}$, recommend ACE inhibitors for patients with current or prior symptoms of $\mathrm{HF}$ and reduced LVEF while beta-blockers are recommended in stable patients (level A evidence). The addition of an aldosterone antagonist is recommended in patients with moderate to severe HF. In the SOLVD echo substudy ${ }^{94}$, Enalapril significantly reduced LV volumes and mass while Carvedilol decreased LV volumes and increased LVEF in the ANZ
HF Collaborative Group ${ }^{95}$. The Val-HeFT echo substudy ${ }^{10}$ showed similar changes in LV dimension and LVEF with valsartan therapy. Aldosterone antagonists (Spironolactone and Elprenone) have shown mortality reduction in NYHA class III and IV HF patients with EF $\leq 35 \%^{96}$ and in post AMI patients with $\mathrm{EF} \leq 40 \%{ }^{97}$.

By the same token, echocardiography can be used to monitor the deleterious effects of cardiotoxic medications such as anthracycline chemotherapy ${ }^{98}$, and treatment can be discontinued based on reduction in LV function.

\section{Cardiac resynchronisation therapy}

Cardiac resychronisation therapy (CRT) has emerged as a therapy for advanced HF patients on optimal medical treatment that favourably affects symptoms, hospitalisation and mortality rate ${ }^{99,100}$. A meta-analysis confirmed a $30 \%$ decrease in hospitalisations and mortality benefit $(24-36 \%)^{101}$ with LV reverse remodelling, improved EF and reduced MR predicting improved survival ${ }^{102}$. Current guidelines ${ }^{103}$ recommend CRT for patients on optimal medical therapy with EF $\leq 35 \%$, in NYHA class III or IV with QRS $\geq 120 \mathrm{~ms}$ although a subgroup of patients with QRS $<120 \mathrm{~ms}$ can benefit from CRT ${ }^{104}$. Single centre studies of CRT response in HF found that improvement was more likely in patients with echocardiographic dyssynchrony at baseline $\mathrm{e}^{70,105,106}$. However, two multicenter studies, the PROSPECT $^{107}$ and ReThinQ trials ${ }^{108}$, used echocardiographic criteria for patient selection and found only modest correlation between echocardiographic indices and CRT benefit. Additionally, a consistent finding from CRT trials, is a lack of benefit in approximately one third of patients (CRT nonresponders) ${ }^{109}$.

\section{ICD implantation}

In HF patients with reduced EF and previous cardiac arrest, ICD has shown mortality benefits despite optimal medical therapy. The AVID ${ }^{110}, \mathrm{CIDS}^{111}$ and $\mathrm{CASH}^{112}$ trials established that ICD improved survival compared with antiarrhythmic agents for secondary prevention of sudden cardiac death (SCD). Other randomised, multicentre studies including MADIT $\mathrm{I}^{19}$ and $\mathrm{II}^{113}$, MUSTT ${ }^{114}$ and the SCD-HeFT ${ }^{115}$, established ICD therapy as effective for primary prevention of SCD in selected patient populations. The LVEF cut offs used in these trials were $<40 \%$ in MUSTT, $<35 \%$ in MADIT I and SCD-HeFT and $<30 \%$ in MADIT II. Based on these trials, present guideline ${ }^{116}$ recommend an echocardiographic LVEF 30-40\% for ICD implantation in specific patient groups.

Many patients eligible for CRT also meet criteria for ICD implantation. The COMPANION trial demonstrated the benefit of combined therapy with CRT and ICD over optimal medical therapy in patients with LVEF $\leq 35 \%$ with prior hospitalisation for $\mathrm{HF}^{117}$.

\section{Correction of ischaemic MR/ MV surgery}

Ischaemic MR following an AMI is associated with increased mortality as demonstrated in the CADILLAC trial ${ }^{118}$ where those with MR had higher mortality rates at 30 days and at one year. A similar increase in mortality over the longer term (five years) with ischaemic MR was reported $^{26}$. Ischemic MR also predicts the development of HF in AMI patients with a little or no symptoms at base- 
line ${ }^{119}$ and HF risk with moderate to severe MR was $\sim 50 \%$ at two years in one series ${ }^{120}$.

Evaluation of ischaemic MR is integral to post AMI assessment, particularly if surgical revascularisation is being considered $^{121}$. Echocardiography both peri- and intra-operatively can assess the mechanism and severity of MR and provide information as to the suitability for valvuloplasty or replacement. Intra-operative TOE tends to downgrade MR severity as a consequence of altered loading conditions under anaesthesia ${ }^{122}$. Mitral valve repair rather than replacement should be attempted in experienced centres ${ }^{123,124}$; however, the advantages of valve repair must be weighed against technical expertise and MR recurrence.

\section{Conclusion}

The evolving echocardiographic technologies have made it an indispensable modality of non-invasive cardiac imaging in the assessment of systolic HF providing information for diagnosis, quantification, therapeutic decision making and for monitoring treatment response. Newer echocardiographic modalities such as TDI, speckle tracking, twist mechanics, as well as RT3DE hold promise for improved accuracy of LV function assessment that would translate into benefits for HF patients by improved clinical care.

\section{References}

1 AHA. Heart disease and stroke statistics - 2004 update. Dallas Texas: American Heart Association, 2004.

2 NHF \& CSANZ. Australian Institute of Health and Welfare. Issue 3 June 2003.

3 AIHW. Heart, stroke and vascular diseases: Australian facts 2004. Canberra: Australian Institute of Health and Welfare, 2004. Available online at www.aihw.gov.au/publications/cvd/hsvd04/hsvd04.pdf [verified June 2007].

4 Najafi F, Dobson AJ, Jamrozik K. Is mortality from heart failure increasing in Australia? An analysis of official data on mortality for 1997-2003. Bull World Health Org 2006; 84: 722-8.

5 Hunt S, Abraham WT, Chin MH, et al. 2009 Focused Update Incorporated Into the ACC/AHA 2005 guidelines for the diagnosis and management of heart failure in adults: a report of the American College of Cardiology Foundation/American Heart Association Task Force on Practice Guidelines: Developed in Collaboration with the International Society for Heart and Lung Transplantation. Circulation 2009; 119: e391-e479.

6 Jessup M, Abraham WT, Casey DE, Feldman AM, Francis GS, Ganiats TG, et al. 2009 Focused Update: ACCF/AHA guidelines for the diagnosis and management of heart failure in adults: a report of the American College of Cardiology Foundation/American Heart Association Task Force on Practice Guidelines: developed in collaboration with the International Society for Heart and Lung Transplantation. Circulation 2009; 119; 1977-2016.

7 Lang RM, Bierig M, Devereux RB, et al. Recommendations for chamber quantification: a report from the American Society of Echocardiography's Guidelines and Standards Committee and the Chamber Quantification Writing Group. J Am Soc Echocardiography 2005; 18: 1440-63.

8 Cintron G, Johnson G, Francis G, Cobb F, Cohn JN. Prognostic significance of serial changes in left ventricular ejection fraction inpatients with congestive heart failure. The V-HeFT VA Cooperative Studies Group. Circulation 1993; 87 Suppl 6: V117-23.

9 Quiñones MA, Greenberg BH, Kopelen HA, Koilpillai C, Limacher MC, Shindler DM, et al. Echocardiographic predictors of clinical outcome in patients with left ventricular dysfunction enrolled in the SOLVD registry and trials: significance of left ventricular hypertrophy. J Am Coll Cardiol 2000; 35: 1237-44.

10 Wong M, Staszewsky L, Latini R, et al. Valsartan benefits left ventricular structure and function in heart failure: Val-HeFT echocardio- graphic study. J Am Coll Cardiol 2002; 40: 970-5.

11 Wong M, Staszewsky L, Latini R, Barlera S, Volpi A, Chiang YT, Val-HeFT Heart Failure Trial Investigators, et al. Severity of left ventricular remodeling defines outcomes and response to therapy in heart failure: Valsartan Heart Failure Trial (Val-HeFT) echocardiographic data. J Am Coll Cardiol 2004; 43: 2022-7.

12 White HD, Norris RM, Brown MA, Brandt PW, Whitlock RM, Wild CJ. Left ventricular end systolic volume as the major determinant of survival after recovery from myocardial infarction. Circulation 1987; 76: 44-51.

13 McManus DD, Shah SJ, Fabi MR, Rosen A, Whooley MA, Schiller NB. Prognostic value of left ventricular end-systolic volume index as a predictor of heart failure hospitalization in stable coronary artery disease: data from the Heart and Soul Study. J Am Soc Echocardiogr 2009; 22 (2): 190-7.

14 Grayburn PA, Appleton CP, DeMaria AN, Greenberg B, Lowes B, Oh J, BEST Trial Echocardiographic Substudy Investigators, et al. Echocardiographic predictors of morbidity and mortality in patients with advanced heart failure: the Beta-blocker Evaluation of Survival Trial (BEST) J Am Coll Cardiol 2005; 45 (7): 1064-71.

15 Otterstad JE, Foreland G, St John Sutton M and Holme I. Accuracy and reproducibility of biplane two-dimensional measurements of left ventricular dimensions and function. Eur Heart J 1997; 18: 507-13.

16 Smart N, Haluska B, Leano R, Case C, Mottram PM, Marwick TH. Determinants of functional capacity in patients with chronic heart failure: role of filling pressure and systolic and diastolic function. Am Heart J 2005; 149: 152-8.

17 St John Sutton M, Pfeffer MA, Plappert T, Rouleau JL, Moyé LA, Dagenais GR, et al. for the SAVE Investigators. Quantitative two dimensional echocardiograohic measurements are major predictors of adverse cardiovascular events after acute myocardial infarction. Circulation 1994; 89: 68-75.

18 Curtis JP, Sokol SI, Wang Y, Curtis JP, Sokol SI, Wang Y. The Association of left ventricular ejection fraction, mortality, and cause of death in stable outpatients with heart failure. J Am Coll Cardiol 2003; 42: 736-42.

19 Moss AJ, Hall WJ, Cannom DS, Daubert JP, Higgins SL, Klein H, Multicenter Automatic defibrillator Implantation Trial Investigators, et al. Improved survival with an implanted defibrillator in patients with coronary disease at high risk for ventricular arrhythmia. $N$ Engl J Med 1996; 335: 1933-40.

20 Anderson B. Two dimensional echocardiographic measurements and calculations. In: The normal Examination and echocardiographic measurements 2nd ed. New York: Wiley; 2006. pp 160.

21 Møller J, Hillis G, Oh J, et al. Wall motion score index and ejection fraction for risk stratification after acute myocardial infarction. Am Heart J 2006; 151 (2): 419-25.

22 Levine RA, Hung J , Otsuji Y, et al. Mechanistic insights into functional mitral regurgitation. Curr Cardiol Rep 2002; 4: 125-9.

23 Gorman RC, McCaughan JS, Ratcliffe MB. Pathogenesis of acute ischaemic mitral regurgitation in three dimensions. $J$ Thorac Cardiovasc Surg 1995; 109: 684-93.

24 Yiu SF, Enriquez-Sarano M, Tribouilloy C, Seward J and Jamil Tajik A. Determinants of the degree of functional mitral regurgitation in patients with systolic left ventricular dysfunction: a quantitative clinical study. Circulation 2000; 102: 1400-14.

25 Lamas GA, Mitchell GF, Flaker GC, Smith SC Jr, Gersh BJ, Basta L, et al. Clinical significance of mitral regurgitation after acute myocardial infarction. Survival and ventricular enlargement investigators. Circulation 1997; 96: 827-33.

26 Grigioni F, Enriquez-Sarano M, Zehr KJ, Bailey KR, Tajik AJ. Ischemic mitral regurgitation: long-term outcome and prognostic implications with quantitative Doppler assessment. Circulation 2001; 103: 1759-64.

27 Godley RW, Wann LS, Rogers EW, Feigenbaum H, Weyman AE. Incomplete mitral leaflet closure in patients with papillary muscle dysfunction. Circulation 1981; 63: 565-71.

28 Dickerman SA, Rubler S. Mitral and tricuspid valve regurgitation in dilated cardiomyopathy. Am J Cardiol 1989; 63: 629-31. 
29 Enriquez-Sarano M. Timing of mitral surgery. Heart 2002; 87: 79-85.

30 Kirkpatrick JN, Vannan MA, Narula J, Lang RM. Echocardiography in heart failure. J Am Coll Cardiol 2007; 50 (5): 381-96.

31 Tei C, Nishimura RA, Seward JB, Tajik AJ. Non invasive Doppler derived myocardial performance index: correlation with simultaneous measurements of cardiac catheterisation measurements. J Am Soc Echocardiography 1997; 10: 169-78.

32 Yeo TC, Dujardin KS, Tei C, Mahoney DW, McGoon MD, Seward JB. Value of a Doppler derived index combining systolic and diastolic time intervals in predicting outcome in primary pulmonary hypertension. Am J Cardiol 1998; 81: 1157-61.

33 Dujardin KS, Tei T, Yeo TC, Rossi AD, Seward JB. Prognostic value of a Doppler index combining systolic and diastolic performance in idiopathic-dilated cardiomyopathy. Am J Cardiol 1998; 82: 1071-6.

34 Arnlov J, Ingelsson E, Riserus U, Andren B, Lind L. Myocardial performance index, a Doppler derived index of global left ventricular function, predicts congestive heart failure in elderly men. Eur Heart $J$ 2004; 25: 2220-5.

35 Mikkelsen KV, Moller JE, Bie P, Ryde H, Videbaek L, Haghfelt T. Tei index and neurohormonal activation in patients with incident heart failure: serial change and prognostic value. Eur J Heart Fail 2006; 8 (6): 599-608.

36 Sutherland GR, Bijnens B, McDicken WN. Tissue Doppler echocardiography: historical perspective and technological considerations. Echocardiography 1999; 16: 445-53.

37 Gohrsan J, Gulati VK, Mandarino WA, Katz WE. Colour coded measures of myocardial velocity throughout the cardiac cycle by tissue Doppler Imaging to quantify regional left ventricular function. Am Heart J 1996; 131: 1203-13.

38 Abraham TP, Dimaano VL, Liang HY. Role of tissue Doppler and strain echocardiography in current clinical practice. Circulation 2007; 116; 2597-609.

39 Wang M, Yip G, Yu CM, Zhang Q, Zhang Y, Tse D, et al. Independent and incremental prognostic value of early mitral annulus velocity in patients with impaired left ventricular systolic function. $J$ Am Coll Cardiol 2005; 45 (2): 272-7.

40 Hillis GS, Møller JE, Pellikka PA, Gersh BJ, Wright RS, Ommen SR, et al. Noninvasive estimation of left ventricular filling pressure by $\mathrm{E} / \mathrm{E}$ ' is a powerful predictor of survival after acute myocardial infarction. J Am Coll Cardiol 2004; 43 (3): 360-67.

41 Wang M, Yip GW, Wang AY, Zhang Y, Ho PY, Tse MK, et al. Tissue Doppler imaging provides incremental prognostic value in patients with systemic hypertension and left ventricular hypertrophy. $J$ Hypertens 2005; 23 (1): 183-91.

42 Fang ZY, Leano R, Marwick TH. Relationship between longitudinal and radial contractility in subclinical diabetic heart disease. Clin Sci (Lond) 2004; 106: 53-60.

43 Sanderson JE, Wang M, Yu CM. Tissue Doppler imaging for predicting outcome in patients with cardiovascular disease. Curr Opin Cardiol 2004; 19: 458-63.

44 Marwick TH, Case C, Leano R, Short L, Baglin T, Cain P, Garrahy P. Use of tissue Doppler imaging to facilitate the prediction of events in patients with abnormal left ventricular function by dobutamine echocardiography. Am J Cardiol 2004; 93: 142-6.

45 Sanderson JE. Heart failure with a normal ejection fraction. Heart 2007; 93: 155-8.

46 Wang M, Yip GW, Wang AY, Zhang Y, Ho PY, Tse MK, et al. Peak early diastolic mitral annulus velocity by tissue Doppler imaging adds independent and incremental prognostic value. J Am Coll Cardiol 2003; 41: 820-6.

47 Nikitin NP, Loh PH, Silva R, Ghosh J, Khaleva OY, Goode K, et al. Prognostic value of systolic mitral annular velocity measured with Doppler tissue imaging in patients with chronic heart failure caused by left ventricular systolic dysfunction. Heart 2006; 92: 775-9.

48 Marwick TH. Measurement of Strain and Strain Rate by echocardiography: ready for prime time? J Am Coll Cardiol 2006; 47 (7): 1313-27.

49 Heimdal A, Stoylen A, Torp H, Skjaerpe T. Real-time strain rate imaging of the left ventricle by ultrasound. J Am Soc Echocardiogr 1998; 11: 1013-19.
50 Leitman M, Lysyansky P, Sidenko S, Shir V, Peleg E, Binenbaum M, et al. Two-dimensional strain-a novel software for real-time quantitative echocardiographic assessment of myocardial function. J Am Soc Echocardiogr 2004; 17: 1021-9.

51 Urheim S, Edvardsen T, Torp H, Angelsen B, Smiseth OA. Myocardial strain by Doppler echocardiography. Validation of a new method to quantify regional myocardial function. Circulation 2000; 102: 1158-64.

52 Edvardsen T, Gerber BL, Garot J, Bluemke DA, Lima JA, Smiseth OA. Quantitative assessment of intrinsic regional myocardial deformation by Doppler strain rate echocardiography in humans: validation against 3 -dimensional tagged magnetic resonance imaging. Circulation 2002; 106: 50-6.

53 Sun JP, Popovic ZB, Greenberg NL, Xu XF, Asher CR, Stewart WJ, Thomas JD. Noninvasive quantification of regional myocardial function using Doppler-derived velocity, displacement, strain rate, and strain in healthy volunteers: effects of aging. J Am Soc Echocardiography 2004; 17: 132-8.

54 Yuda S, Short L, Leano R, Marwick TH. Myocardial abnormalities in hypertensive patients with normal and abnormal left ventricular filling: a study of ultrasound tissue characterisation and strain. Clin Sci (Lond) 2002; 103: 283-93.

55 Fang ZY, Yuda S, Anderson V, Short L, Case C, Marwick TH. Echocardiographic detection of early diabetic myocardial disease. $J$ Am Coll Cardiol 2003; 41: 611-17.

56 Sutherland GR, Di Salvo G, Claus P, D’hooge J, Bijnens B. Strain and strain rate imaging: a new clinical approach to quantifying regional myocardial function. J Am Soc Echocardiogr 2004; 17 : 788-802.

57 Park TH, Nagueh SF, Khoury DS, Kopelen HA, Akrivakis S, Nasser $\mathrm{K}$, et al. Impact of myocardial structure and function post infarction on diastolic strain measurements: implications for assessment of myocardial viability. Am J Physiol Heart Circ Physiol 2006; 290: H724-31.

58 Mottram PM, Haluska B, Leano R, Cowley D, Stowasser M, Marwick TH. Effect of aldosterone antagonism on myocardial dysfunction in hypertensive patients with diastolic heart failure. Circulation 2004; 110: 558-65.

59 Yip G, Khandheria B, Belohlavek M, Pislaru C, Seward J, Bailey K, et al. Strain echocardiography tracks dobutamine induced decrease in regional myocardial perfusion in non-occlusive coronary stenosis. $J$ Am Coll Cardiol 2004; 44: 1664-71.

60 Weidemann F, Jamal F, Kowalski M, Kukulski T, D’Hooge J, Bijnens $\mathrm{B}$, et al. Can strain rate and strain quantify changes in regional systolic function during dobutamine infusion, beta blockade and atrial pacing? J Am Soc Echocardiography 2002; 15: 416-24.

61 Hoffmann R, Altiok E, Nowak B, Heussen N, Kühl H, Kaiser HJ, et al. Strain rate measurement by Doppler echocardiography allows improved assessment of myocardial viability in patients with depressed left ventricular function. J Am Coll Cardiol 2002; 39: 443-49.

62 Xie GY, Berk MR, Smith MD, Gurley JC, DeMaria AN. Prognostic value of Doppler transmitral flow patterns in patients with congestive heart failure. J Am Coll Cardiol 1994; 24: 132-9.

63 Wang M, Yip G, Yu CM, Zhang Q, Zhang Y, Tse D, et al. Independent and incremental prognostic value of early mitral annulus velocity in patients with impaired left ventricular systolic dysfunction. J Am Coll Cardiol 2005; 45: 272-7.

64 Nagueh SF, Middleton KJ, Kopelen HA, Zoghbi WA, Quiñones MA. Doppler Tissue imaging: a non invasive technique for evaluation of left ventricular relaxation and estimation of filling pressures. J Am Coll Cardiol 1997; 30: 1527-33.

65 Yamamoto T, Oki T, Yamada H, Tanaka H, Ishimoto T, Wakatsuki $\mathrm{T}$, et al. Prognostic value of the atrial systolic mitral annular motion velocity in patients with left ventricular systolic dysfunction. $J$ Am Soc Echocardiogr 2003; 16: 333-9.

66 Fung JW, Yu CM, Yip G, Zhang Y, Chan H, Kum CC, Sanderson JE. Variable left ventricular activation pattern in patients with heart failure and left bundle branch block. Heart 2004; 90: 17-19.

67 Bleeker GB, Schalij MJ, Molhoek SG, Holman ER, Verwey HF, 
Steendijk P, et al. Frequency of left ventricular dyssynchrony in patients with heart failure and a narrow QRS complex. Am J Cardiol 2005; 95 (1): 140-142.

68 Yu CM, Lin H, Zhang Q, Sanderson JE. High prevalence of left ventricular systolic and diastolic asynchrony in patients with congestive heart failure and normal QRS duration. Heart 2003; 89: 54-60.

69 Pitzalis MV, Iacoviello M, Romito R, Massari F, Rizzon B, Luzzi G, et al. Cardiac resynchronization therapy tailored by echocardiographic evaluation of ventricular asynchrony. J Am Coll Cardiol 2002; 40: 1615-22.

70 Bax JJ, Bleeker GB, Marwick TH, Molhoek SG, Boersma E, Steendijk P, et al. Left ventricular dyssynchrony predicts response and prognosis after cardiac resynchronization therapy. J Am Coll Cardiol 2004; 44: 1834-40.

71 Yu CM, Zhang Q, Fung JW, Chan HC, Chan YS, Yip GW, et al. A novel tool to assess systolic dyssynchrony and identify responders of cardiac resynchronization therapy by tissue synchronization imaging. $J$ Am Coll Cardiol 2005; 45: 677-84.

72 Yu CM, Fung JW, Zhang Q, Chan CK, Chan YS, Lin H, et al. Tissue Doppler imaging is superior to strain rate imaging and postsystolic shortening on the prediction of reverse remodeling in both ischemic and nonischemic heart failure after cardiac resynchronization therapy. Circulation 2004; 110: 66-73.

73 Yu CM, Fung WH, Lin H, Zhang Q, Sanderson JE, Lau CP. Predictors of left ventricular reverse remodeling after cardiac resynchronization therapy for heart failure secondary to idiopathic dilated or ischemic cardiomyopathy. Am J Cardiol 2003; 91: 684-88.

74 Suffoletto MS, Dohi K, Cannesson M, Saba S, Gorcsan J 3rd. Novel speckle-tracking radial strain from routine black-and-white echocardiographic images to quantify dyssynchrony and predict response to cardiac resynchronization therapy. Circulation 2006; 113 (7): 960-68.

75 Mor-Avi V, Sugeng L, Lang RM. Contemporary Reviews in Cardiovascular Medicine: Real-Time 3-Dimensional Echocardiography an Integral Component of the Routine Echocardiographic Examination in Adult Patients? Circulation 2009; 119: 314-29.

76 Kapetanakis S, Kearney MT, Siva A, Gall N, Cooklin M, Monaghan MJ. Real-time three-dimensional echocardiography - a novel technique to quantify global left ventricular mechanical dyssynchrony. Circulation 2005; 112 (7): 992-1000.

77 Sengupta P, Jamil Tajik A, Chandrasekaran K, Khandheria BK. Twist mechanics of the left ventricle. J Am Coll Cardiol Cardiovasc Im 2008; 1 (3): 366-76.

78 Smiseth OA, Remme EW. Regional left ventricular electric and mechanical activation and relaxation. J Am Coll Cardiol 2006; 47: 173-4.

79 Ingels NB Jr, Hansen DE, Daughters GT 2nd, Stinson EB, Alderman EL, Miller DC. Relation between longitudinal, circumferential, and oblique shortening and torsional deformation in the left ventricle of the transplanted human heart. Circ Res 1989; 64: 915-27.

80 Narula J, Vannan MA, DeMaria AN. Of that Waltz in my heart. J Am Coll Cardiol 2007; 49: 917-20.

81 Weyman AE. The year in Echocardiography. J Am Coll Cardiol 2007; 49 (11): 1212-9.

82 Dong SJ, Hees PS, Siu CO, Weiss JL, Shapiro EP. MRI assessment of LV relaxation by untwisting rate: a new isovolumic phase measure of tau. Am J Physiol Heart Circ Physiol 2001; 281: H2002-9.

83 Notomi Y, Lysyansky P, Setser RM, Shiota T, Popovic ZB, MartinMiklovic MG, et al. Measurement of ventricular torsion by 2D ultrasound speckle tracking imaging. J Am Coll Cardiol 2005; 45: 2034-41.

84 Notomi Y, Setser RM, Shiota T, Martin-Miklovic MG, Weaver JA, Popovic ZB, et al. Assessment of left ventricular torsion deformation by Doppler tissue imaging: validation study with tagged magnetic resonance imaging. Circulation 2005; 111: 1141-7.

85 Takeuchi M, Borden WB, Nakai H, Nishikage T, Kokumai M, Nagakura T, et al. Reduced and delayed untwisting of the left ventricle in patients with hypertension and left ventricular hypertrophy: a study using two dimensional speckle tracking imaging. Eur Heart $J$ 2007; 28: 2756-62.
86 Takeuchi M, Nishikage T, Nakai H, Kokumai M, Otani S, Lang RM. The assessment of left ventricular twist in anterior wall myocardial infarction using two-dimensional speckle tracking imaging. J Am Soc Echocardiogr 2007; 20: 36-44.

87 Sugeng L, Weinert L, Lang RM. Left ventricular assessment using real time three dimensional echocardiography. Heart 2003; 89 (Suppl 3iii): 29-36.

88 Corsi C, Lang RM, Veronesi F, Weinert L, Caiani EG, MacEneaney P, et al. Volumetric quantification of global and regional left ventricular function from real time three-dimensional echocardiographic images. Circulation 2005; 112: 1161-70.

89 Yu CM, Bax JJ, Monaghan M, Nihoyannopoulos P. Echocardiographic assessment of dyssynchrony for predicting a favourable response to cardiac resynchronisation therapy. Heart 2004; 90 Suppl 6: vi17-22.

90 Jenkins C, Bricknell K, Hanekom L, Marwick TH. Reproducibility and accuracy of echocardiographic measurements of left ventricular parameters using real-time three dimensional echocardiography. JACC 2004; 44: 878-86.

91 Sugeng L, Mor-Avi V, Weinert L, Niel J, Ebner C, SteringerMascherbauer R, et al. Quantitative assessment of left ventricular size and function: side by side comparison of real time three dimensional echocardiography and computed tomography with magnetic resonance reference. Circulation 2006; 114: 654-61.

92 Soliman OII, Geleijnse ML, Theuns DAMJ. Effects of left ventricular pacing site and outcome after CRT using novel real-time three dimensional echocardiography technique to define site of latest activation (abstr). J Am Soc Echocardiogr 2007; 20: 558.

93 Kahlert P, Plicht B, Erbel R, Buck T. Direct assessment of proximal jet area in mitral regurgitation using real time three dimensional colour Doppler echocardiography: comparison with two dimensional proximal jet width and implications for the assessment of asymmetric proximal jet area (abstr). J Am Soc Echocardiogr 2007; 20: 560.

94 Greenberg B, Quinones MA, Koilpillai C, Limacher M, Shindler D, Benedict C. Effects of long-term enalapril therapy on cardiac structure and function in patients with left ventricular dysfunction: results of SOLVD echocardiographic substudy. Circulation 1995; 91: 2573-81.

95 Doughty RN, Whalley GA, Gamble G, MacMahon S, Sharpe N, Australia-New Zealand Heart Failure Research Collaborative Group. Left ventricular remodelling with carvedilol in patients with congestive heart failure due to ischaemic heart disease. J Am Coll Cardiol 1997; 29: 1060-6.

96 Pitt B, Zannad F, Remme WJ, Cody R, Castaigne A, Perez A, et al. The effect of spironolactone on morbidity and mortality in patients with severe heart failure. Randomised Aldactone Evaluation Study Investigators. New Engl J Med 1999; 341: 709-17.

97 Pitt B, Remme W, Zannad F, Neaton J, Martinez F, Roniker B, Eplerenone Post-Acute Myocardial Infarction Heart Failure Efficacy and Survival Study Investigators, et al. Eplerenone, a selective aldosterone blocker, in patients with left ventricular dysfunction after myocardial infarction. New Engl J Med 2003; 348: 1309-21.

98 Youssef G, Links Ml. The prevention and management of cardiovascular complications of chemotherapy in patients with cancer. Am J Cardiovasc Drugs 2005; 5: 233-43.

99 Bristow MR, Saxon LA, Boehmer J, Krueger S, Kass DA, De Marco T, Comparison of Medical Therapy, Pacing, and Defibrillation in Heart Failure (COMPANION) Investigators, et al. Cardiac-resynchronization therapy with or without an implantable defibrillator in advanced chronic heart failure. New Engl J Med 2004; 350: 2140-50.

100 Cleland JG, Daubert JC, Erdmann E, Freemantle N, Gras D, Kappenberger L, Tavazzi L; Cardiac Resynchronization-Heart Failure (CARE-HF) Study Investigators, et al. The effect of cardiac resynchronization on morbidity and mortality in heart failure. New Engl J Med 2005; 352: $1539-49$.

101 Bradley DJ, Bradley EA, Baughman KL, Berger RD, Calkins H, Goodman SN, et al. Cardiac resynchronization and death from progressive heart failure: a meta-analysis of randomized controlled trials. JAMA 2003; 289: 730-40.

102 Yu CM, Fung JWH, Lin H, Zhang Q, Sanderson JE, Lau CP, et al. 
Left ventricular reverse remodelling but not clinical improvement predicts long-term survival after cardiac resynchronisation therapy. Circulation 2005; 112: 1580-6.

103 ACC/AHA/HRS 2008 Guidelines for Device-Based Therapy of Cardiac Rhythm Abnormalities. A report of the ACC/AHA Task Force on Practice Guidelines. J Am Coll Cardiol 2008; 51 (21): e1-62.

104 Leclercq C, Faris O, Tunin R, Johnson J, Kato R, Evans F, et al. Systolic improvement and mechanical resynchronization does not require electrical synchrony in the dilated failing heart with left bundle-branch block. Circulation 2002; 1061: 760-63.

105 Penicka M, Bartunek J, De Bruyne B, Vanderheyden M, Goethals M, De Zutter M, et al. Improvement in left ventricular function after cardiac resynchronisation s predicted by tissue Doppler imaging echocardiography. Circulation 2004; 109 (8): 978-83.

106 Mele D, Pasanisi G, Capasso F, De Simone A, Morales MA, Poggio $\mathrm{D}$, et al. Left intraventricular myocardial deformation dyssynchrony identifies responders to cardiac resynchronisation therapy in patients with heart failure. Eur Heart J 2006; 27 (9): 1070-8.

107 Chung ES, Leon AR, Tavazzi L, Sun JP, Nihoyannopoulos P, Merlino $\mathrm{J}$, et al. Results of the predictors of Response to CRT (PROSPECT) Trial. Circulation 2008; 117: 2608-16.

108 Beshai JF, Grimm R, Rethin Q Investigators. Cardiac-resynchronisation therapy in heart failure with narrow QRS complexes. New Engl J Med 2007; 357: 2461-71.

109 Kashani A, Barold SS. Significance of QRS complex duration in patients with heart failure. J Am Coll Cardiol 2005; 46: 2183-92.

110 The Antiarrhythmics versus Implantable Defibrillators (AVID) Investigators. A comparison of antiarrhythmic-drug therapy with implantable defibrillators in patients resuscitated from near-fatal ventricular arrhythmias. N Engl J Med 1997; 337: 1576-83.

111 Connolly SJ, Gent M, Roberts RS, Dorian P, Roy D, Sheldon RS. Canadian implantable defibrillator study (CIDS): a randomized trial of the implantable cardioverter defibrillator against amiodarone. Circulation 2000; 101: 1297-302.

112 Kuck KH, Cappato R, Siebels J, Ruppel R. Randomized comparison of antiarrhythmic drug therapy with implantable defibrillators in patients resuscitated from cardiac arrest: the Cardiac Arrest Study Hamburg (CASH). Circulation 2000; 102: 748-54.

113 Moss AJ, Zareba W, Hall WJ, Klein H, Wilber DJ, Cannom DS, Multicenter Automatic Defibrillator Implantation Trial II Investigators, et al. Prophylactic implantation of a defibrillator in patients with myocardial infarction and reduced ejection fraction. New Engl J Med 2002; 346: 877-83.
114 Buxton AE, Lee KL, Fisher JD, Josephson ME, Prystowsky EN, Hafley G. A randomized study of the prevention of sudden death in patients with coronary artery disease. Multicenter Unsustained Tachycardia Trial Investigators. N Engl J Med 1999; 341: 1882-90.

115 Bardy GH, Lee KL, Mark DB, et al. Amiodarone or an implantable cardioverter-defibrillator for congestive heart failure. New Engl J Med 2005; 352: 225-37.

116 Epstein AE, DiMarco JP, Ellenbogen KA, Estes NA 3rd, Freedman RA, Gettes LS, et al. ACC/AHA/HRS Guidelines for Device-Based Therapy of Cardiac Rhythm Abnormalities: Executive Summary. $J$ Am Coll Cardiol 2008; 51 (21): 2085-105.

117 Bristow MR, Saxon LA, Boehmer J, Krueger S, Kass DA, De Marco T. Comparison of Medical Therapy, Pacing, and Defibrillation in Heart Failure (COMPANION) Investigators, et al. Cardiac-resynchronisation therapy with or without an implantable defibrillator in advanced chronic heart failure. New Engl J Med 2004; 350: 2140-50.

118 Pellizzon GG, Grines CL, Cox DA, Stuckey T, Tcheng JE, Garcia $\mathrm{E}$, et al. Importance of mitral regurgitation in patients undergoing percutaneous coronary intervention for acute myocardial infarction: the Controlled Abciximab and Device Investigation to Lower Late Angioplasty Complications (CADILLAC) trial. J Am Coll Cardiol 2004; 43: 1368.

119 Grigioni F, Detaint D, Avierinos JF, Scott C, Tajik J, Enriquez-Sarano M. Contribution of ischaemic mitral regurgitation to congestive heart failure after myocardial infarction. J Am Coll Cardiol 2005; 45: 260-7.

120 Aronson D, Goldsher N, Zukermann R, Kapeliovich M, Lessick J, Mutlak D, et al. Ischaemic mitral regurgitation and risk of heart failure after myocardial infarction. Arch Intern Med 2006; 166: 2362-8.

121 Gillinov AM, Wierup PN, Blackstone EH, Bishay ES, Cosgrove DM, White J, Lytle BW, et al. Is repair preferable to replacement for ischaemic mitral regurgitation? J Thorac Cardiovasc Surg 2001; 122: 1125.

122 Aklog L, Filsoufi F, Flores KQ, Chen RH, Cohn LH, Nathan NS, et al. Does coronary artery bypass grafting alone correct moderate ischemic mitral regurgitation? Circulation 2001; 104 (suppl 1): I-68-75.

123 Lavie CJ, Gersh BJ. Mechanical and electrical complications of acute myocardial infarction. Mayo Clin Proc 1990; 65: 709.

124 David,TE. Techniques and results of mitral valve repair for ischaemic mitral regurgitation. J Card Surg 1994; 9: 274. 